\title{
Ubiquitin D
}

National Cancer Institute

\section{Source}

National Cancer Institute. Ubiquitin D. NCI Thesaurus. Code C38438.

Ubiquitin $\mathrm{D}(165 \mathrm{aa}, \sim 18 \mathrm{kDa}$ ) is encoded by the human UBD gene. This protein plays a role in both protein modification and ubiquitinated protein degradation. 